\title{
VEGETATION PATTERNS ASSOCIATED WITH A LARGE ROCK PLATE IN THE MEEHAN RANGE, TASMANIA
}

\author{
by Kevin E. Leeson and J. B. Kirkpatrick
}

(with two tables, one plate and three text-figures)

LEESON, K. E. \& KiRKPATRICK, J. B., 2004 (29:x): Vegetation patterns associated with a large rock plate in the Meehan Range, Tasmania. Papers and Proceedings of the Royal Society of Tasmania 138: 47-52. https://doi.org/10.26749/rstpp.138.47 ISSN 0080-4703.

School of Geography \& Environmental Studies, University of Tasmania, Private Bag 78, Hobart, Tasmania 7001, Australia.

(KEL*, JBK). *Author for correspondence.

Rock outcrops provide unusual environmental conditions, often being the habitats of disjunct populations or rare species. A large rock plate on Mt Direction, within the Meehan Range, southeastern Tasmania, supports an open-heath of unusual floristic composition, and contains the only known population of zothamnus reflexifolius Leeson $\&$ Rozefelds. Four florisric communities occur on and around the plate, forming a sequence from the open-heath on the plate itself to tall woodland with a dense understorey of small trees where rock and bare ground cover are low. Patterns of moisture availability, related to soil depth, aspect, slope and topographic position seem to best explain the floristic, structural and species richness patterns in the area.

Key Words: rock outcrop, skeletal soils, Ozothamnus reflexifolius, Tasmania.

\section{INTRODUCTION}

Rock plates and the skeletal soils that surround them provide an extreme habitat for vascular plant species within any region (e.g., Kruckerberg \& Rabinowitz 1985, Baskin \& Baskin 1988, Mishio 1992, Medail \& Verlaque 1997, Porembski \& Barthlott 2000, Poot \& Lambers 2003). Complex patterns of shedding and accumulation of moisture in response to variations in topography and soil depth can induce high local heterogeneity in the vegetation, which often contains disjunct populations of common species, and rare local endemics (Prober \& Austin 1990, Prober 1992, Coates 1996, Coates et al. 1999, Maisels et al. 2000, Wolf et al. 2000, Schonswetter et al. 2003). While shallow or absent soils induce moisture stress, they also provide a barrier to fire, allowing rare firesensitive species to survive in fire-prone landscapes (Coates 1996, Coates et al. 1999, Clarke 2002, Leeson \& Kirkpatrick 2004). The vegetation of the rock plates of Tasmania has been classified by Gilfedder et al. (1997). However, one of the most biologically interesting rock plates in Tasmania, the sole location of the shrub species, Ozothamnus reflexifolius Leeson \& Rozefelds, was not sampled in that study.

The present paper provides a description of the vegetation of this rock plate and directly adjacent areas, and relates variation in species composition to environmental variables.

\section{THE STUDY AREA}

The study area, located in southeastern Tasmania is centred on an unusually large dolerite rock plate (fig. 1). It is approximately 2 ha in area and is divided by an occasional winter creek. Slopes within the study area vary from gentle to $60^{\circ}$. Altitude varies from 200 to $340 \mathrm{~m}$ above sea level and aspect ranges from northwesterly through to southwesterly.

Rainfall is less than $600 \mathrm{~mm}$ per annum and is generally distributed evenly throughout the year. Annual potential evaporation is approximately $1250 \mathrm{~mm}$. Application of the environmental lapse rate for Mt Wellington (Nunez \& Colhoun 1986) indicates that the mean daily maximum temperature of the warmest month is approximately $18^{\circ} \mathrm{C}$, while the mean daily minimum temperature of the coolest month is approximately $2.2^{\circ} \mathrm{C}$.

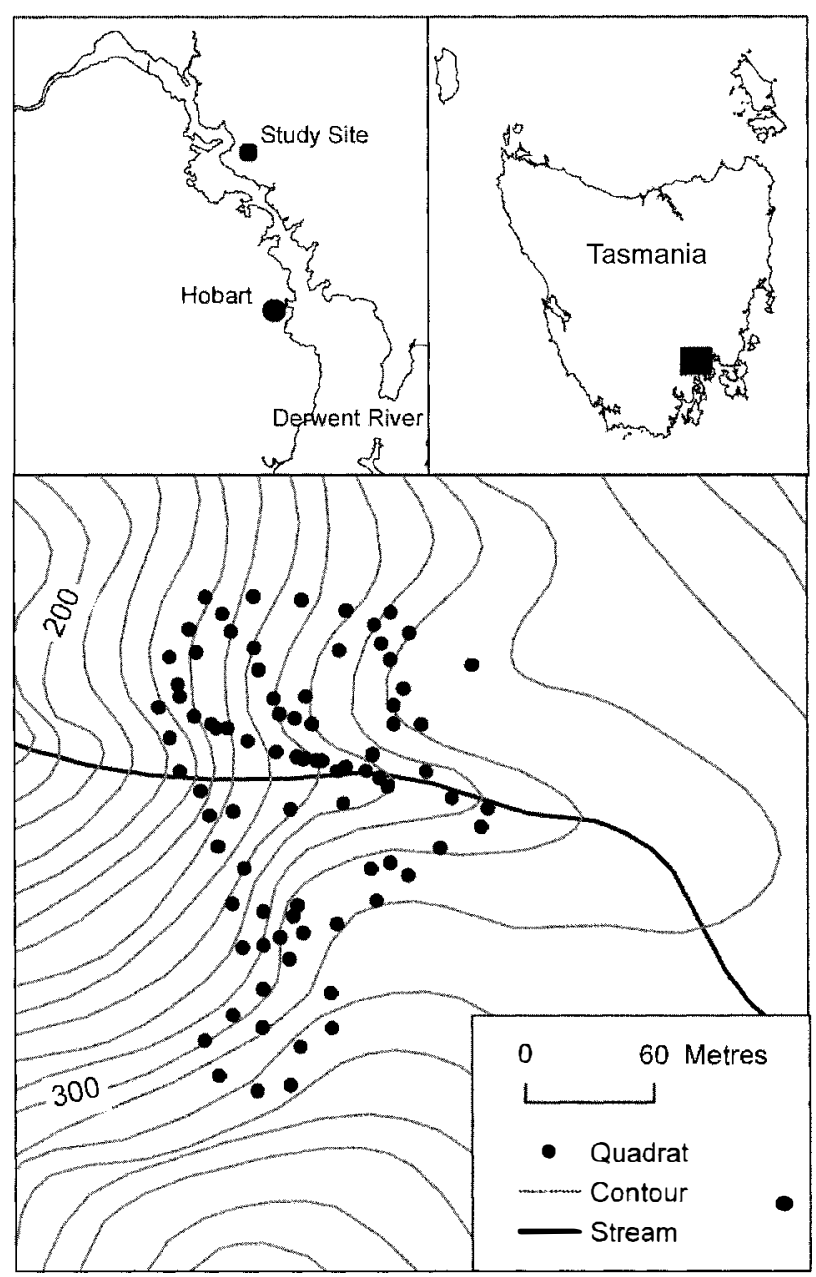

FIG. 1-Location map, and topography and quadrat locations at the study area. 
Soils occurring on the surface of the rock plate are shallow, stony clay-loams containing relatively high levels of organic matter. A gradational change into a shallow duplex clayloam over a thin reddish-brown clay horizon occurs away from the rock plate. In contrast, these soils contain very little organic matter. Deeper duplex red-brown clay-loam soils are found most distant from the rock plate. The $\mathrm{pH}$ of all soils is typically within the range 5.5-6.0.

\section{METHODS}

Eighty-three $5 \times 5 \mathrm{~m}$ quadrats were placed within the study area (fig. 1). Quadrat sampling size was determined by utilising the techniques described by Wiegert (1962). All vascular plant species present within quadrats were recorded and their percentage cover estimated by the one observer within the following Braun-Blanquet cover classes: $1=0-0.5 \%, 2=$ $0.5-5 \%, 3=5-25 \%, 4=25-50 \%, 5=50-75 \%, 6=>75 \%$. Bare ground, rock and litter were also scored within each quadrat and assigned a relevant cover score. Geocoordinates for all quadrats were recorded during September 2001 with a Garmin GPS 12 receiver. Altitude, slope and aspect for each quadrat were also recorded.

All data were entered into the ecological community database, DECODA (Minchin 1994) and an initial sorting of presence-absence data for all 83 quadrats was performed by the polythetic divisive classificatory program, TWINSPAN (Hill 1979). The resulting table was resorted and communities discriminated based on co-occurrence of species.

Global non-metric multidimensional scaling was used to perform an ordination of all 83 quadrats using a BrayCurtis (1957) dissimilarity matrix (fig. 2). Ten starting configurations were used in two dimensions, using a maximum of 100 repetitions. A stress ratio stopping value of 0.99 and a minimum stress stopping value of 0.01 was applied. Depending on the data structure, ANOVA, the Kruskal-Wallis $\mathrm{H}$ test or Chi-squared were used to test the significance of variation in environmental and vegetation variables between groups. Results were taken to be significant if $\mathrm{P}<0.05$. Multiple regression or generalised linear modelling (GLM) were used to develop explanations of variation in the ordination axis scores and species richness.

Nomenclature for all species follows Buchanan (1999).

\section{RESULTS}

Four communities were discriminated from the sorted table. Community 1 is characterised by the presence of Ozothamnus reflexifolius and a relatively high frequency of Acianthus caudatus R.Br., Allocasuarina verticillata Labill., Austrostipa rudis (Sprengel) S.W.L. Jacobs \& J. Everett, Carex breviculmis R.Br., Epacris acuminata Benth., Poa rodwayi Vickery and Schoenus apogon Roemer \& Schultes. Other species present in this community included Acacia mearnsii De Wild., Astroloma bumifusum (Cav.) R.Br., Austrodanthonia caespitosa (Gaudich.) H.P. Linder, Cheilanthes austrotenuifolia Quirk \& Chambers, Correa reflexa (Labill.) Vent., Dodonata viscosa Jacq., Hibbertia riparia (R.Br. ex DC.) Hoogl., Lepidosperma gunnii Boeck., Lomandra longifolia Labill., Ozothammusscutellifolius Hook.f., Pelargonium inodorum Willd., Plantago varia R.Br., Themeda triandra Forsskal and Thysanotus patersonii R.Br. (table 1). The quadrats in this community largely fell within the openheath on the rock plate (pl. 1) and have greater mean species richness than all other communities (table 2 ).

Community 2 has a high frequency of Ozothamnus reflexifolius, Allocasuarina verticillata, Astroloma humifusum, Dodonaea viscosa, Lepidosperma gunnii and Poa rodwayi. Additional species recorded are similar to community 1 except for the absence of Epacris acuminata and Pelargonium inodorum. Species present in this community but absent in community 1 included Bossiaea prostrata R.Br., Bursaria spinosa Cav., Eucalyptus globulus Labill., Oxalis perennans Haw. and Pimelea nivea Labill. (table 1). The quadrats in this community largely occurred in Allocasuarina verticillata low open-forest (pl. 1). The community has lower mean species richness than community 1 and higher mean species richness than community 4 (table 2 ).

Community 3 had high frequencies of Allocasuarina verticillata, Astroloma humifusum, Dodonaea viscosa, Lomandra longifolia and Poa rodwayi. These species co-occur in communities 2 and 3 in similar proportions. However, species absent from community 3 but present in communities 1 and 2 include Ozothamnus reflexifolius, Austrodanthonia caespitosa, Carex breviculmis, Hibbertia riparia, Schoenus apogon, Themeda triandra and Thysanotus patersonii. Species present here but absent from the first two communities include Acacia melanoxylon R.Br. in W.T.Aiton, Allocasuarina verticillata, Asplenium flabellifolium Cav., Bedfordia linearis (Labill.) DC., Eucalyptus pulchella Desf. and Pimelea humilis R.Br. (table 1). The quadrats in community 3 occur in vegetation in which large emergent Eucalyptus globulus occur above a smaller tree layer consisting of Acacia mearnsii, Acacia melanoxylon, Allocasuarina verticillata, Eucalyptus pulchella, Eucalyptus viminalis and Exocarpos cupressiformis (pl. 1). This community has lower mean species richness than community 1 (table 2 ).

Community 4 is similar to the other three communities in having a high frequency of Allocasuarina verticillata, Astroloma humifusum and Lomandra longifolia. Overall, species composition of this community is similar to community 3, except for the presence of Acaena novaezelandiae Kirk and Austrodanthonia caespitosa and the absence of Acacia verticillata, Acacia melanoxylon, Eucalyptus pulchella and Pimelea nivea (table 1). The quadrats in this community largely fall within $A$. verticillata woodland (pl. 1). The community has lower mean species richness than communities 1 and 2 .

The four communities occupy largely distinct sections of ordination space (fig. 3), with all communities being statistically distinct on axis 1 , and community 3 being distinct from all other communities on axis 2 (table 2).

The environmental variable that most strongly differentiated the communities as a whole was rock cover (table 2). The scores on ordination axis 1 were also most strongly differentiated by this variable (simplified so that classes 4,5 and 6 of rock cover were merged, GLM, P< $0.001)$. Aspect was significant as a covariate $(\mathrm{P}<0.05)$ in the rock cover GLM model for axis 1 . A model with the same explanatory components was obtained for mean species richness, which covaried with the ordination score on axis 1 (table 2). Axis 2 of the ordination was very weakly explained by a regression model consisting of altitude and slope (mds2 $=1.44-0.0131$ Slope -0.00229 Altitude, P $<0.05, \mathrm{R}-\mathrm{Sq}=8.9 \%)$. 
TABLE 1

Percentage frequency of taxa in communities

\begin{tabular}{|c|c|c|c|c|}
\hline \multirow[b]{2}{*}{ Species } & \multicolumn{4}{|c|}{ Community } \\
\hline & 1 & 2 & 3 & 4 \\
\hline Acianthus caudatus & 91.67 & 3.23 & 18.75 & 16.67 \\
\hline Austrostipa rudis & 83.33 & 25.81 & 6.25 & 4.17 \\
\hline Epacris acuminata & 75 & - & 12.5 & 4.17 \\
\hline Carex breviculmis & 66.67 & 19.35 & - & - \\
\hline Schoenus apogon & 66.67 & 16.13 & - & - \\
\hline Lepidosperma gunnii & 58.33 & 54.84 & 18.75 & 41.67 \\
\hline Themeda triandra & 50 & 12.9 & - & - \\
\hline Cheilanthes austrotenuifolia & 50 & 25.81 & 18.75 & 37.5 \\
\hline Austrodanthonia caespitosa & 33.33 & 19.35 & - & 4.17 \\
\hline Hibbertia riparia & 33.33 & 3.23 & - & - \\
\hline Thysanotus patersonii & 25 & 6.45 & - & - \\
\hline Plantago varia & 25 & 3.23 & 12.5 & 4.17 \\
\hline Pelargoninm inodorum & 8.33 & - & - & - \\
\hline Ozothamnus scutellifolius & 8.33 & 6.45 & 6.25 & 8.33 \\
\hline Ozothamnus reflexifolius & 100 & 100 & - & - \\
\hline Pimelea nivea & - & 48.39 & 6.25 & - \\
\hline Bossiaea prostrata & _- & 3.23 & - & _- \\
\hline Poa rodwayi & 91.67 & 100 & 100 & 4.17 \\
\hline Dodonaea viscosa & 16.67 & 64.52 & 87.5 & 41.67 \\
\hline Lomandra longifolia & 33.33 & 41.94 & 81.25 & 66.67 \\
\hline Bursaria spinosa & - & 38.71 & 50 & 20.83 \\
\hline Eucalyptus pulchella & - & - & 37.5 & - \\
\hline Pimelea humilis & - & - & 37.5 & 20.83 \\
\hline Corred reflexa & 25 & 22.58 & 31.25 & 8.33 \\
\hline Eucalyptus globulus & - & 6.45 & 25 & 12.5 \\
\hline Asplenium flabellifolium & - & - & 18.75 & 4.17 \\
\hline Acacia verticillata & - & - & 12.5 & - \\
\hline Acacia melanoxylon & - & - & 6.25 & - \\
\hline Bedfordia linearis & - & - & 6.25 & 4.17 \\
\hline Allocasuarina verticillata & 75 & 90.32 & 81.25 & 95.83 \\
\hline Astroloma humifusum & 41.67 & 58.06 & 62.5 & 66.67 \\
\hline Oxalis perennans & - & 3.23 & 37.5 & 45.83 \\
\hline Acacia mearnsii & 8.33 & 25.81 & 12.5 & 41.67 \\
\hline Acaena novae-zelandiae & - & - & - & 4.17 \\
\hline
\end{tabular}

Figures in bold are the highest percentage frequencies for taxa.

TABLE 2

Characteristics of communities

\begin{tabular}{|c|c|c|c|c|c|}
\hline & \multicolumn{4}{|c|}{ Community } & \multirow[b]{2}{*}{$\mathrm{p}$} \\
\hline & 1 & 2 & 3 & 4 & \\
\hline Mean mds 1 & $1.63 \mathrm{~A}$ & $1.34 \mathrm{~B}$ & $0.85 \mathrm{C}$ & $0.36 \mathrm{D}$ & 0.000 (ANOVA) \\
\hline Mean mds 2 & $0.48 \mathrm{~A}$ & $0.66 \mathrm{~A}$ & $1.04 \mathrm{~B}$ & $0.57 \mathrm{~A}$ & 0.000 (ANOVA) \\
\hline Mean species richness & $10.67 \mathrm{~A}$ & $8.00 \mathrm{~B}$ & $7.88 \mathrm{BC}$ & $6.50 \mathrm{C}$ & 0.000 (ANOVA) \\
\hline Bare ground $>25 \%$ cover $(\%)$ & 50 & 67 & 31 & 29 & $0.018\left(\mathrm{Chi}^{2}\right)$ \\
\hline Rock $>5 \%$ cover $(\%)$ & 83 & 58 & 6 & 0 & $0.000\left(\mathrm{Chi}^{2}\right)$ \\
\hline Mean elevation (m) & 242 & 260 & 285 & 300 & $0.036(\mathrm{KW})$ \\
\hline Mean slope $\left(^{\circ}\right)$ & $17.08 \mathrm{~A}$ & $10.90 \mathrm{~B}$ & $8.75 \mathrm{~B}$ & $11.88 \mathrm{AB}$ & 0.014 (ANOVA) \\
\hline Mean aspect $\left({ }^{\circ}\right)$ & $257 \mathrm{~A}$ & $288 \mathrm{~B}$ & $262 \mathrm{~A}$ & $292 B$ & 0.007 (ANOVA) \\
\hline
\end{tabular}

ANOVA = Analysis of variance, $\mathrm{KW}=$ Kruskal-Wallis H-test. Values with any letter the same in a row are statistically identical at $p>0.05$ 

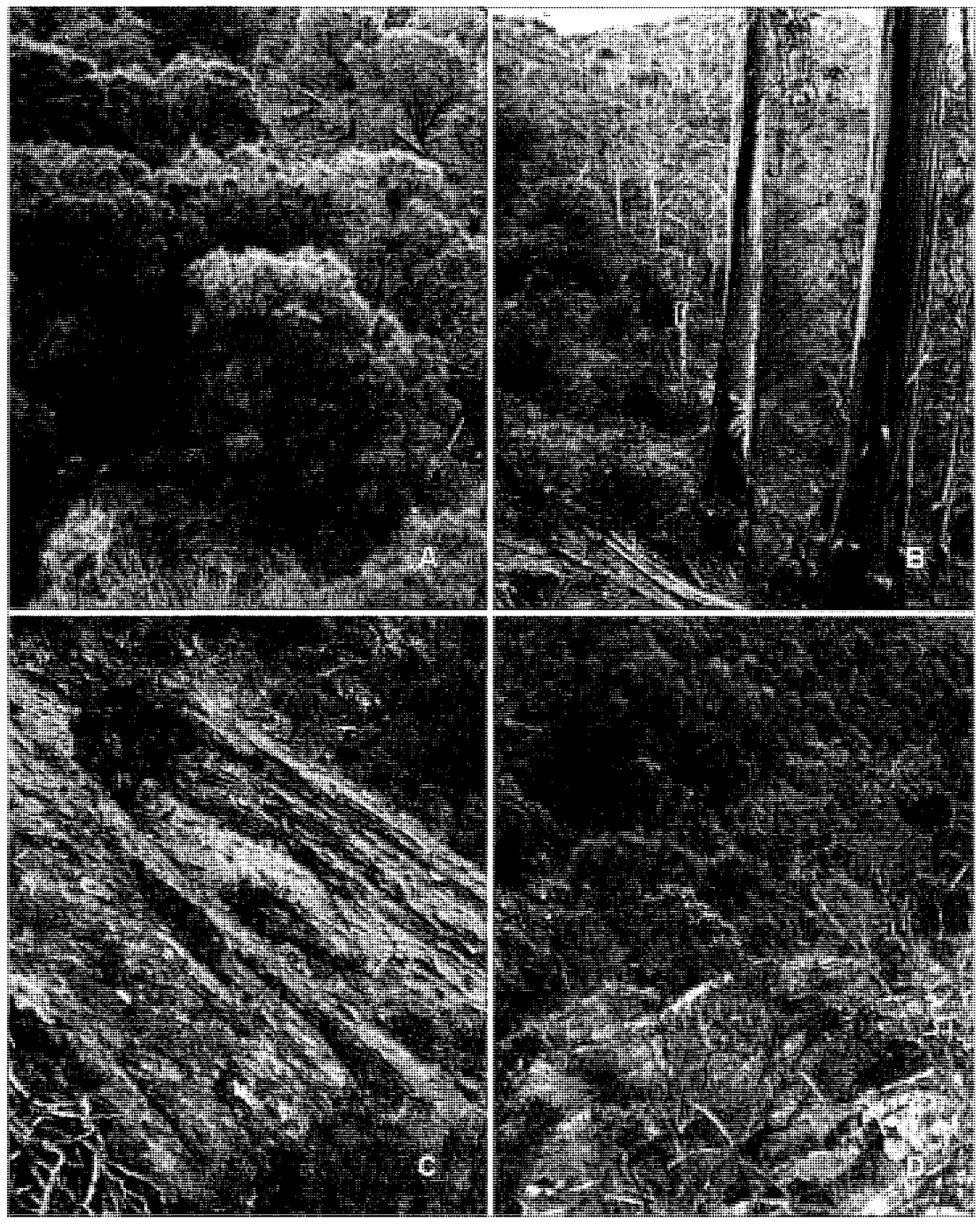

PLATE 1

Typical views of vegetation types at the study area: $(\boldsymbol{A})=$ Allocasuarina verticillata woodland; $(\boldsymbol{B})=$ Eucalyptus globulus tall woodland; $(\boldsymbol{C})=$ rock face vegetation; $(\boldsymbol{D})=$ open-heath.

\section{DISCUSSION}

Relative degrees of availability of soil moisture seem most consistent with the variation in the vegetation of the study area, with the major axis of floristic variation, and variation in species richness, being strongly related to rock cover and bare ground. This corresponds with a structural change from sparse heath on almost solid rock to tall eucalypt woodland over a dense second stratum of trees where rock cover is negligible. Because soil tends to accumulate more on gentle slopes than on steep slopes, it is not surprising that the rock plate heath is on steeper slopes than most of the other structural communities. The role of aspect in influencing floristic variation is less clear.

Community 1, which occurs in the rockiest situations, has a west-south-west mean aspect, as does the more mesic community 3 , while communities 2 and 4 have west-northwest aspects. Given that the strongest and driest winds are northwesterly in southeastern Tasmania, and that insolation is greater on the more northerly slopes, there seems likely to be a moderation of droughtiness related to more southerly aspects. Topographic position is also important for moisture relationships, with the most mesic communities being at the base of the large rock plate.

The rock plate provides the core of the habitat of Ozothamnus reflexifolius, only known from this site (Leeson \& Rozefelds 2003, Leeson \& Kirkpatrick 2004), which even apart from the presence of this species, supports an unusual heath assemblage, not described by Kirkpatrick \& Harris (1999) in their statewide conspectus of heath communities, nor by Gilfedder et al. (1997) in their classification of Tasmanian rock plate communities. The rock plate with the most similar vegetation to the one described here is on the Lake Leake Road on the seaward slope of the Eastern Tiers, in woodland dominated by $E$. pulchella. This had a Bray-Curtis similarity of only 35\% (Leeson and Kirkpatrick 2004). The Mt Direction rock plate is therefore of extremely high conservation significance. 

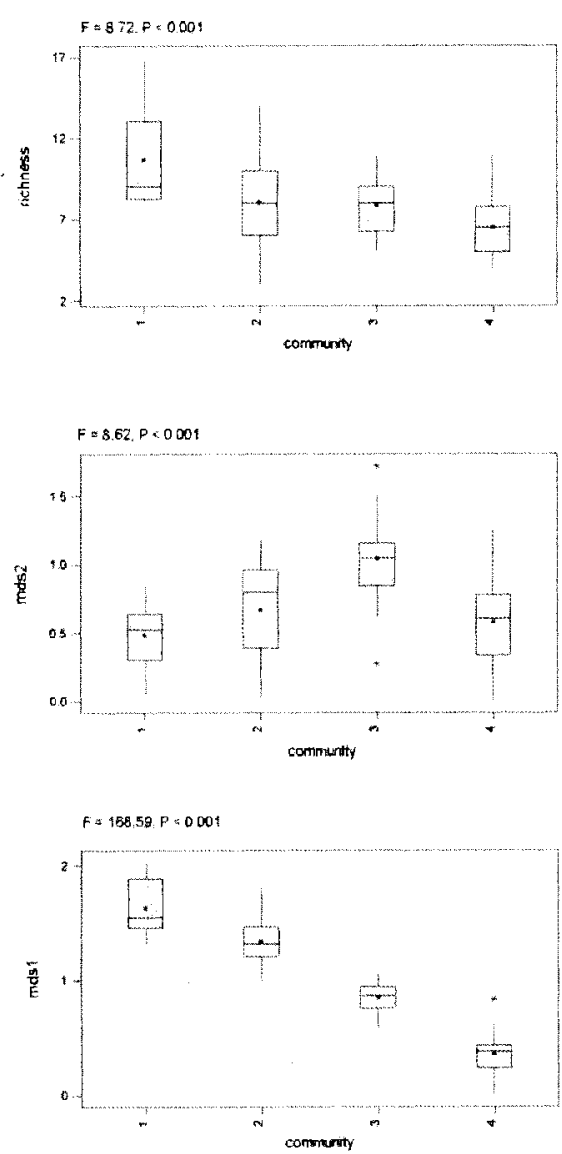

FIG. 2 - Box plots of: $m$ ds axis 1 score by community; $m$ ds axis 2 score by community; species richness by community. The boxes enclose the 25-75 percentiles, the lines show the ranges and the dots represent the means.

\section{ACKNOWLEDGMENTS}

Richard Schahinger from the Threatened Species Unit, Department of Primary Industries, Water and the Environment, Tasmania, is acknowledged for discovery of the population of Ozothamnus reflexifolius. Patrick Murray kindly provided assistance with photography and data collection. Mark Fountain, Megan Brown and Michelle Lang from the Royal Tasmanian Botanical Gardens provided advice on various issues and technical support. Mick Russel and Rob Anders kindly provided assistance with GIS applications. Janet Smith assisted with corrections to improve the manuscript.

\section{REFERENCES}

BASKIN, J.M. \& BASKIN, C.C., 1988: Endemism in rock outcrop plant communities of unglaciated eastern United States: an evaluation of the roles of edaphic, genetic and light factors. Journal of Biogeography 15: 829-840.

BRAY, J.R. \& CURTIS, J.T., 1957: An ordination of the upland forest communities of southern Wisconsin. Ecological Monographs 27: 325-349.

BUCHANAN, A.M., 1999: A census of the vascular plants of Tasmania and index to 'The student's flora of Tasmania'. Tasmanian Herbarium Occasional Publication 6, Hobart.

CLARKE, P.J., 2002. Habitat islands in fire-prone vegetation: do

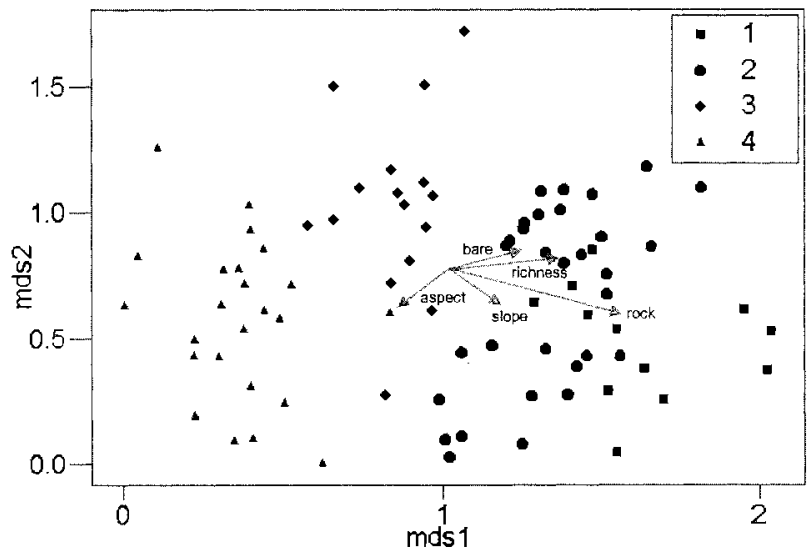

FIG. 4 - Significant vectors in two-dimensional ordination space, showing the distribution of the four communities.

landscape features influence community composition? Journal of Biogeography 29: 677-684.

COATES, F, 1996: Ecological and biogeographical correlates of rarity in two narrow endemics in Tasmania: Spyridium microphyllum (E. Muell. ex Reiseck) Druce and Spyridium obcordatum (Hook. f.) W. M. Curtis. Unpubl. PhD thesis. University of Tasmania, Hobart.

COATES, F., KirkPatrick, J.B. \& Minchin, P.R., 1999: Towards an explanation of the causes of the rarity of two Tasmanian Spyridium species. Australian Journal of Ecology 24: 11-17.

GILFEDdER, L., KiRKPATRICK, J.B. \& ZIEGELER, D., 1997: Characteristics and conservation status of rock pavement vegetation in lowland perhumid and subhumid Tasmania. A report to the Australian Heritage Commission from the University of Tasmania. $50 \mathrm{pp}$.

HILL, M.O., 1979: TWINSPAN: A FORTRAN Program for arranging multivariate data in an ordered two way table by classification of the individual and attributes. Cornell University, New York.

KiRKPATRICK, J.B. \& HARRIS, S., 1999. The disappearing heath revisited. Tasmanian Environment Centre, Hobart.

KRUCKERBERG, A.R. \& RABINOWITZ, D., 1985: Biological aspects of endemism in higher plants. Annual Review of Ecology and Systematics 16: 447-479.

LEESON, K.E. \& ROZEFELDS, A.C., 2003: A new endemic Ozothamnus species (Asteraceae) from Tasmania, Australia. Australian Systematic Botany 16: 317-322.

LEESON, K.E. \& KIRKPATRICK, J.B., 2004: Ecological and physiological explanations for the restriction of a Tasmanian species of Ozothamnus to a single population. Australian Journal of Botany 52: 39-45.

MAisels, F.G., CHEEK, M. \& WILD, C., 2000: Rare plants on Mount Oku summit, Cameroon. Oryx 34: 136-140.

MEDAIL, F. \& VERLAQUE, R., 1997: Ecological characteristics and rarity of endemic plants from south-eastern France and Corsica: implications for biodiversity conservation. Biological Conservation 80: 269-281.

MiNCHIN, P.R., 1994: DECODA. Database for ecological community data. Version 2.04. Research School of Pacific Studies, ANU, Canberra.

MisHIO, M., 1992: Adaptations to drought in five woody species co-occurring on shallow soil ridges. Australian Journal of Plant Physiology 19: 539-553.

NunEZ, M. \& COLHOUN, E.A., 1986: A note on air temperature lapse rates on Mt Wellington, Tasmania. Papers and Proceedings of the Royal Society of Tasmania 120: 11-15.

POOT, P. \& LAMBERS, H., 2003: Are trade-offs in allocation pattern and root morphology related to species abundance? A congenic comparison between rare and common species 
in the south-western Australian flora. Journal of Ecology 91: 58-67.

POREMBSKI, S. \& BARTHLOTT, W., 2000: Granitic and gneissic outcrops (inselbergs) as centers of diversity for desiccationtolerant vascular plants. Plant Ecology 151: 19-28.

PROBER, S.M., 1992: Environmental influences on the distribution of the rare Eucalyptus paliformis and the common $E$. fraxinoides. Australian Journal of Botany 17: 51-65.

Prober, S.M. \& AUSTIN, M.P., 1990: Habitat peculiarity as a cause of rarity in Eucalyptus paliformis. Australian Journal of Ecology 16: 189-205.

SChonswetter, P., Tribsch, A., Schneeweiss, G.M. \& NikLfELD, H., 2003: Disjunctions in relict alpine plants: phylogeography of Androsace brevis and A. wulfeniana (Primulaceac). Botanical Journal of the Linnean Society 141: 437-446.

WIEGERT, R.G., 1962: The selection of an optimum quadrat size for sampling the standing crop of grasses and forbs. Ecology 43: 125-129.

WOLF A.T., HARRISON, S.P., \& HAMRICK, J.L., 2000: Influence of habitat patchiness on genetic diversity and spatial structure of a serpentine endemic plant. Conservation Biology 14: 454-463.

(accepted 31 May 2004) 